\title{
Anatomic and tissue characteristics in goats fed for extended periods with residue of castor biodiesel production
}

\section{Características anatômicas e teciduais em cabras alimentadas por longos períodos com resíduo da indústria do biodiesel da mamona}

\author{
Cláudio Henrique de Almeida Oliveira ${ }^{1 *}$; Liliane Moreira Silva ${ }^{1}$; Aline Maia Silva ${ }^{1}$; \\ César Carneiro Linhares Fernandes ${ }^{1}$; Karla Leylanne Sousa Góes ${ }^{1}$; \\ Sandra Silva Duarte ${ }^{1}$; Fabiana Vinhas Rodrigues ${ }^{1}$; Luciana Relly Bertolini²; \\ Frederico José Bezerra ${ }^{3}$; Manoel Adrião Gomes Filho ${ }^{4}$; Davide Rondina ${ }^{5}$
}

\begin{abstract}
Twenty-five adult crossbred goats, divided in two groups, were fed over a period of 16 months with diets based on Tifton hay and concentrate feed with (DCM) or without (WDCM) detoxified castor bean meal as a substitute for soybean meal. Throughout 480 days, blood samples were taken to measure lactate dehydrogenase, aspartate aminotransferase, alanine aminotransferase, urea, albumin and creatinine. The animals were euthanized, and the anatomical components (lungs, heart, spleen, liver, kidneys, tongue, empty stomach, empty intestines, omentum, cardiac and renal adipose tissue), carcass and commercial cuts (shoulder, ham, loin, ribs and neck) were weighed. Thereafter, an anatomic dissection of the loin was performed, separating the muscle, adipose and bone tissues. On the muscular part of the loin, longissimus dorsi, the proximate composition, fatty acid profile and the expression of SEW-1, IGF-I and IGF-II were analyzed. A higher incidence of bone tissue was observed in the anatomical dissections of the loin and a lower incidence of fat in the proximate composition of the longissimus dorsi of the DCO group compared to the WDCM group $(\mathrm{p}<0.05)$. The expression of the IGF-II and SEW-1 genes was higher ( $\mathrm{p}<0.001$ for each) in the muscle tissue of the DCM animals. Thus, using detoxified castor bean meal for long periods does not produce significant changes in the anatomical composition of the loin or the proximate composition of the longissimus dorsi. However, the differences in gene expression suggest the need for new investigations and care when using this product for animal feeding.
\end{abstract}

Key words: Castor bean, goat, muscle tissue

\section{Resumo}

Vinte e cinco cabras adultas mestiças, divididas em dois grupos, foram alimentadas por um período de 16 meses com dietas a base de feno de tifton e concentrado sem (SFMD) e com farelo de mamona destoxificado (FMD) em substituição ao farelo de soja. Aos 480 dias, foram coletadas amostras de

\footnotetext{
${ }^{1}$ Students, School of Veterinary Medicine, State University of Ceará, Fortaleza, Ceará, Brazil. E-mail: claudiohao@hotmail. com; liligomesvet@hotmail.com; nine.maia@yahoo.com.br; caancesar@gmail.com; leylanne_goes20@hotmail.com; sandrinhamargi@hotmail.com; fabianavinhas@hotmail.com

${ }^{2}$ Prof. School of Medicine, University of Fortaleza, Ceará, Brazil. E-mail: lucianabertolini@uol.com.br

${ }^{3}$ Prof. School of Nutrition, University of Fortaleza, Ceará, Brazil. E-mail: bezerra@unifor.br

${ }^{4}$ Prof. School of Veterinary Medicine, Federal Rural University of Pernambuco, Pernambuco, PE, Brazil. E-mail: manoeladriao@, yahoo.com.br

${ }^{5}$ Prof. School of Veterinary Medicine, State University of Ceará, Fortaleza, Ceará, Brazil. E-mail: davide.rondina@uece.br

* Author for correspondence
} 
sangue para dosagem de lactato desidrogenase, aspartato aminotransferase, alanina aminotransferase, uréia, albumina e creatinina. Em seguida, os animais foram sacrificados e foi realizada a pesagem dos componentes anatômicos (pulmões, coração, baço, fígado, rins, língua, estomago vazio, intestino vazio, omento, tecido adiposo cardíaco e renal), da carcaça e dos cortes comerciais (paleta, pernil, lombo, costelas e pescoço). Posteriormente, foi realizada a dissecção anatômica do lombo, separando tecidos muscular, adiposo e ósseo. Na porção muscular do lombo, Longissimus dorsii, foram analisadas a composição centesimal, o perfil de ácidos graxos e a expressão dos genes SEW-1, IGF-I e IGF-II. Verificou-se uma incidência superior de tecido ósseo na dissecção anatômica do lombo e uma incidência inferior de gordura na composição centesimal do Longissimus dorsii do grupo FMD em relação ao grupo $\operatorname{SFMD}(\mathrm{p}<0,05)$. A expressão do gene IGF-II resultou superior $(\mathrm{p}<0,001)$ no tecido muscular dos animais FMD, bem como para o gene SEW-1 ( $<<0,001)$. Diante do exposto, podemos concluir que a utilização do farelo de mamona destoxificado por períodos prolongados não produz alterações importantes nas composições anatômica do lombo e na composição centesimal do Longissimus dorsii. Entretanto, as diferenças na expressão de genes sugerem novas investigações e cautela no uso deste produto na alimentação animal.

Palavras-chave: Mamona, cabra, tecido muscular

\section{Introduction}

There is a high demand by governmental programs to implement sustainable and economical forms of production and usage of biodiesel from oilseeds (RODRIGUES, 2007). In northeastern Brazil, mainly in the semiarid region, government incentives focus on social inclusion of family farming (ABREU; VIEIRA; RAMOS, 2006). Thus, in recent years, incentives have promoted the diffusion of castor seeds (Ricinus communis L.) due to its great edaphoclimatic adaptability to semiarid regions (BELTRÃO et al., 2005). However, a major worry regarding the biodiesel chain of production is the destination of its byproducts, because for each ton of castor oil produced, an estimated 1.2 tons of byproducts are produced (AZEVEDO; LIMA, 2001).

Among its byproducts, castor meal is considered an important option for animal feeding due to its high protein value (ABDALLA et al., 2008), which makes this a potential product for the sustainable exploration of marginalized semiarid areas (BELTRÃO et al., 2005). Due to these characteristics, castor meal may become an alternative food for the Brazilian northeastern herds, as they exhibit low production of grains for concentrated feed formulation. This might provide a way to generate income for small cattle producers.
Despite its potential, castor meal contains a powerful protein-based toxin, ricin, that acts by inactivating ribosomes; a low-toxicity alkaloid, ricinine; and a group of allergenic proteins known as CB-1A (BARBIERI; BATTLELLI; STIRPE, 1993). These components make it impossible to use in feed. Because of these obstacles, castor bean meal has been explored mainly as an organic fertilizer around the world (AZEVEDO; LIMA, 2001).

That being said, many studies have developed techniques to detoxify this byproduct (ANANDAN et al., 2005; MADEIRA JUNIOR; MACEDO; MACEDO, 2011), making it available for animal feeding. In studies on sheep fed with castor meal that was detoxified using calcium oxide $(\mathrm{CaO})$ for 21 days, increases in protein and dry matter digestibility were observed, with no negative effects on the hepatic function of the animals (OLIVEIRA et al., 2010). Barros et al. (2011), when feeding heifers with castor meal that was detoxified with $\mathrm{CaO}$ for 84 days, also noticed increases in dry matter and protein digestibility, with no reports of intoxicated animals.

However, there have been no clear studies on the effects of using castor bean for long periods in animal products, especially goat products. This information would be necessary to commercialize these animals and to ensure safe food for the people of the semiarid regions, where goat products 
represent an important source of protein.

The European Food Safety Authority (2008) reports that health risks from consuming milk, meat and eggs from animals fed with castor byproducts are very low. That report quoted the study conducted by Robb et al. (1974), who fed cattle for 14 months with diets containing treated castor residue and found no residue accumulation in the muscles, no abnormal effects on the animals and no apparent transfer of ricinine to the milk. Watson (1905) suggests that ricin may be present in the milk of lactating guinea pigs that receive such agglutinins through injection, as the offspring that were fed with such milk became resistant to subsequent injections of the toxin. In a more recent study performed by Vieira et al. (2010) on sheep fed with castor meal detoxified for 70 days, no effects were noted on carcass characteristics or non-carcass components of finishing animals.

To thoroughly assess the effects of long-term feeding with detoxified castor meal, the present study aimed to analyze the anatomical and muscle tissue characteristics of goats fed for 480 days with castor residue.

\section{Materials and Methods}

\section{Castor residue detoxification procedure}

The castor meal was obtained at the Brasil Óleo de Mamona facility, located in Salvador, Bahia. For the detoxification treatment, we followed the procedure developed by Anandan et al. (2005) and adapted by Oliveira (2008). Briefly, $1 \mathrm{~kg}$ of calcium oxide (Carbomil Química S/A, Fortaleza, Ceará, Brazil; at least $88 \%$ of total oxides) diluted in $9 \mathrm{~L}$ of water was added to the byproduct, with a concentration of $60 \mathrm{~g}$ of $\mathrm{CaO}$ for every kilogram of meal. After 12-18 hours, which was the time needed for the detoxification process to happen, the material was dried for subsequent storage and usage. The absence of ricin after the detoxification process was verified through $12 \%$ polyacrylamide gel electrophoresis in non-denaturing conditions (native-PAGE) in a Bio-Rad PowerPac Basic Supply vertical mini-gel system. The gel was stained with Coomassie Blue R250 solution.

\section{Animals and experimental design}

The experiment was performed at the Dr. Esaú Accioly de Vasconcelos Agricultural Experiments Farm, Guaiúba, CE, Brazil, which belongs to the School of Veterinary Medicine/UECE, located at $4^{\circ}$ $02^{\prime}$ S, $38^{\circ} 30^{\prime}$ W. Twenty-five adult crossbred goats were separated in two homogenous groups according to weight and age (group without detoxified castor meal (WDCM, $\mathrm{n}=12$ ): $42.94 \pm 3.1 \mathrm{~kg}$ and 43.88 \pm 0.95 months; group with detoxified castor meal (DCM, $\mathrm{n}=13$ ): $41.64 \pm 2.1 \mathrm{~kg}$ and $45.54 \pm 0.92$ months). In the first group of does the dietary composition included: Tifton hay and concentrate feed ( $80 \%$ corn, $15 \%$ soy meal, $5 \%$ minerals). In the second group of does the dietary composition included: Tifton hay and concentrate feed with detoxified castor meal instead of soy meal (80\% corn, $15 \%$ castor meal, $5 \%$ minerals). Concentrate were isoenergetic $(74 \% \mathrm{TDN})$ and isonitrogenous (14\% crude protein on dry matter). All animals received diets for maintenance according to the National Research Council (NRC, 2007). A mixture of urea/ammonium sulfate (9:1) was used to adjust the crude protein content of the diet to eliminate the difference between the feeds. The chemical analysis of the castor meal before and after detoxification is shown in Table 1 to demonstrate that there was no loss in the chemical quality of the residue in this process. The dry matter (DM), mineral matter (MM), crude protein $(\mathrm{CP})$ and ether extract (EE) were analyzed according to the procedures described by Silva and Queiroz (2002), and the neutral detergent fiber (NDF), acid detergent fiber (ADF) and lignin (LIG) contents were analyzed according to Van Soest, Robertson and Lewis (1991). 
Table 1. Chemical analysis of the castor meal.

\begin{tabular}{lcc}
\hline Parameters (\% DM) & Detoxified castor meal & Castor meal \\
\hline Dry matter & 91.74 & 91.81 \\
Crude protein & 36.14 & 41.35 \\
Ether extract & 2.94 & 2.00 \\
Mineral residue & 17.63 & 10.65 \\
Neutral detergent fiber & 38.43 & 40.07 \\
Acid detergent fiber & 30.63 & 33.80 \\
\hline
\end{tabular}

Source: Elaboration of the authors.

The diets were offered twice a day during 16 months, in the early morning and at the end of the afternoon, allowing 5 to $10 \%$ of orts, and the females were maintained in collective stalls with $a d$ libitum water and mineral salt.

\section{Blood samples and determination of metabolites}

Before euthanizing the animals, we took blood samples through jugular venipuncture using heparinized vacutainer tubes before the animals were fasted. The blood samples were centrifuged at $3000 \mathrm{rpm}$ for 15 minutes, and the plasma obtained was stored in a freezer at $-20{ }^{\circ} \mathrm{C}$ for subsequent quantification of the main hepatic and renal function-related metabolites. The plasma concentrations of lactate dehydrogenase (LDH), aspartate aminotransferase (AST), alanine aminotransferase (ALT), urea, albumin and creatinine were determined using spectrophotometry in an automated biochemical analyzer (Labmax 240, Labtest ${ }^{\circledR}$ ) using commercial kits $\left(\right.$ Labtest $^{\circledR}$, Lagoa Santa, MG, Brazil).

\section{Anatomical and carcass components}

After 480 days of feeding, the animals were weighed, followed by a solid and liquid fast for 16 hours. Subsequently, the animals were weighed again to obtain the fasting live weight and then euthanized according to RIISPOA standards (BRASIL, 1980). Next, skinning, evisceration and removal of the head and extremities were performed.
After the evisceration, the anatomical components were weighed (lungs, heart, spleen, liver, kidneys, tongue, empty stomach, empty intestines, omentum and cardiac and renal adipose tissue).

After evisceration, the carcass was weighed to obtain the hot carcass weight. The carcasses were then stored at $4{ }^{\circ} \mathrm{C}$ for 24 hours. Next, they were again weighed to obtain the cold carcass weight. Then, the carcasses were longitudinally cut into two half-carcasses, and the following commercial cuts were performed on the left half-carcass: shoulder, ham, loin, ribs and neck, as described by Cesar and Sousa (2007) and Silva Sobrinho (2001). The shoulder was obtained by disarticulation of the scapula. The ham was delineated by the cut between the last lumbar vertebra and first sacral vertebra. The loin was obtained through the six lumbar vertebrae. The rib (false and real) was obtained between the first and thirteenth thoracic vertebrae. The neck was obtained by removing the seven cervical vertebrae by performing an oblique cut.

\section{Dissection and tissue analysis}

The loin of all euthanized animals was identified and stored in a freezer at $-18{ }^{\circ} \mathrm{C}$ in parafilm for further tissue composition analysis. The loin was thawed inside plastic bags in a refrigerator at $10{ }^{\circ} \mathrm{C}$ for 20 hours for the tissue analysis. In the dissection, the muscle, adipose and bone tissues were separated using a scalpel, knife and anatomical clamp. The adipose tissue consisted of external (located below the skin) and intermuscular (located below the deep 
fascia, associated with the muscle) fat. The muscle tissue consisted of all the muscles dissected after the complete removal of the attached subcutaneous and intermuscular fat. The bone tissue was obtained after the complete removal of all the attached muscle and fat. After the dissection, each tissue was weighed.

The proximate composition of the muscle was determined according to the AOAC (1990), and the moisture was obtained by drying a sample in an oven at $105{ }^{\circ} \mathrm{C}$ until it reached a constant weight. The nitrogen content was determined by the Kjeldahl method and converted to crude protein using a factor of 6.25 . The fixed mineral residue was determined by incineration at $550{ }^{\circ} \mathrm{C}$. The total lipids were determined by a hot extraction process using an organic solvent (hexane) at $120{ }^{\circ} \mathrm{C}$.

\section{Analysis of the fatty acids of the loin}

The fatty acid profile was quantified using gas chromatography, attached to a flame ionization detector (model GCMSQP5050A, SHIMADZU, Nakagyo-ku, Kyoto, Japan). The separation took place in a CARBOWAX 20M (SUPELCO) fused silica capillary column (stationary phase, polyethylene glycol) that was $60 \mathrm{~m}$ long, with an internal diameter of $0.53 \mathrm{~mm}$ and $1 \mu \mathrm{m}$ film thickness. A sample of 2 $\mu \mathrm{L}$ of the methyl ester samples was injected into a split/splitless injector at $250{ }^{\circ} \mathrm{C}$. The chromatograms containing the data on retention time and the fatty acid area percentages were stored in Peak simple software (ARI Instruments, USA). The fatty acids were identified by comparing the retention time of the methyl esters of the samples with authentic standards of fatty acid esters (Merck, USA).

\section{Gene expression analysis}

Immediately after euthanasia, 25 samples of muscle tissue were collected using a sterile scalpel, scissors and clamps. The tissue was washed in RNase-free DEPC water, and Sel W, insulin-like growth factor (IGF)-I and IGF-II gene expression was analyzed (Table 2). The samples were stored in cryotubes containing Trizol ${ }^{\circledR}$ (Invitrogen, Carlsbad, C, USA), refrigerated in nitrogen and stored at -80 ${ }^{\circ} \mathrm{C}$. RNA was extracted using Trizol ${ }^{\circledR}$ according to the manufacturer's recommendations. The RNA concentration of the samples was quantified using a spectrophotometer with $260 \mathrm{~nm}$ wavelength (Bionnate 3, Thermo Scientific), and the integrity was evaluated using denaturing $1 \%$ agarose gel electrophoresis.

The cDNA was synthesized from $1.25 \mu \mathrm{g}$ of total RNA using random hexamer primers (Promega, Madison, WI, USA) and the ImPromIITM Reverse Transcriptase kit (Promega), according to the manufacturer's recommendations. Semi-quantitative PCR was performed using the primers (in a final volume of $20 \mu \mathrm{l}$ ) in the presence of $1 \mu \mathrm{l}$ of cDNA, 2 IU of Taq DNA Polymerase (Fermentas), $0.5 \mathrm{mM}$ of each specific primer, $200 \mathrm{mM}$ of each dNTP, $2.0 \mathrm{mM}$ of $\mathrm{MgCl}_{2}$ and $1 \mathrm{x}$ PCR Buffer. The initial PCR program used was $94{ }^{\circ} \mathrm{C}$ for 5 minutes followed by 36 cycles of 94 ${ }^{\circ} \mathrm{C}$ for $1 \mathrm{~min}, 58-60{ }^{\circ} \mathrm{C}$ for $1 \mathrm{~min}$ and $72{ }^{\circ} \mathrm{C}$ for $1 \mathrm{~min}$. The final incubation was at $72{ }^{\circ} \mathrm{C}$ for 10 min. The PCR products were visualized by $1 \%$ agarose gel electrophoresis. The gene expression was quantified by densitometry using Image $J^{\circledR}$ software (Image ${ }^{\circledR}$, National Institutes of Health, Bethesda, MD, USA). 
Table 2. PCR primer details.

\begin{tabular}{ccc}
\hline Genes & Accession number & Sequence \\
\hline SelW & NM_001163225.1 & f:cggcttcttgaagtgttc \\
& & r:tctctgcctttaggccacat \\
IGF-I & HQ731040.1 & r:tgctctccagttcgtgtgt \\
& r:ttgagaggcgeagtacatct \\
IGF-II & GQ246165.1 & f:tcgtgctgctatgctgcttacc \\
& & r:actgcttccaggtgtcagattgg \\
B-Actin & JQ409458.1 & r:caccacacttctacaacgagc \\
\end{tabular}

Source: Elaboration of the authors.

\section{Statistical analysis}

An entirely randomized design was used for the statistical analysis, with two diets and 12 repetitions. The data were submitted to analysis of variance (ANOVA) using the GLM procedure of SAS $^{\circledR}$ software (SAS ${ }^{\circledR}$, Inc., Cary, NC, USA), with the food group as the tested factor. Means were compared using Student's $t$ test. Gene expression data were transformed into $\log _{10}$ values.

\section{Ethics and biosafety committee}

This study was approved by the Ethics Committee for Animal use of the State University of Ceará (Comissão de Ética para o uso de Animais da Universidade Estadual do Ceará - CEUA-UECE), protocol number 09503497-8/82.

\section{Results}

No significant differences in plasma metabolites were observed $(p>0.05)$ between the food groups at the time of euthanasia (Table 3). Similarly, the weights of the anatomical components and carcass (Table 4) did not differ between both groups $(\mathrm{p}>0.05)$.

Table 3. Means and standard errors of the plasma metabolite concentrations after 480 days of feeding.

\begin{tabular}{lccc}
\hline Parameter & WDCM & DCM & Sig. \\
\hline LDH (U/L) & $743.42 \pm 20.06$ & $767.54 \pm 35.74$ & $\mathrm{~ns}$ \\
ALT (U/L) & $20.42 \pm 0.67$ & $21.08 \pm 1.38$ & $\mathrm{~ns}$ \\
AST (U/L) & $91.67 \pm 5.26$ & $103.61 \pm 6.18$ & $\mathrm{~ns}$ \\
Urea (mg/dL) & $24.25 \pm 2.24$ & $22.38 \pm 1.97$ & $\mathrm{~ns}$ \\
Albumin (g/dL) & $2.48 \pm 0.06$ & $2.26 \pm 0.08$ & $\mathrm{~ns}$ \\
Creatinine (mg/dL) & $0.80 \pm 0.03$ & $0.82 \pm 0.03$ & $\mathrm{~ns}$ \\
\hline
\end{tabular}

ns: not significant $(\mathrm{p}>0.05) ; *(\mathrm{p}<0.05) ; * *(\mathrm{p}<0.01)$.

Sig.: Significance.

Source: Elaboration of the authors. 
Table 4. Means and standard errors of the anatomical and carcass components after 480 days of feeding.

\begin{tabular}{|c|c|c|c|}
\hline Parameters & WDCM & DCM & Sig. \\
\hline Live weight $(\mathrm{kg})$ & $42.93 \pm 2.64$ & $41.64 \pm 2.76$ & ns \\
\hline Fasting weight $(\mathrm{kg})$ & $40.81 \pm 2.60$ & $39.28 \pm 2.70$ & ns \\
\hline \multicolumn{4}{|l|}{ Anatomical Components (g) } \\
\hline Lungs & $273.15 \pm 26.42$ & $268.33 \pm 27.50$ & ns \\
\hline Heart & $165.38 \pm 11.87$ & $158.33 \pm 12.35$ & ns \\
\hline Spleen & $93.85 \pm 31.43$ & $92.50 \pm 32.71$ & ns \\
\hline Liver & $450.77 \pm 28.15$ & $446.67 \pm 29.30$ & ns \\
\hline Kidneys & $91.12 \pm 6.29$ & $89.17 \pm 6.55$ & ns \\
\hline Tongue & $127.69 \pm 7.15$ & $136.67 \pm 7.44$ & ns \\
\hline Empty Stomach & $1332.31 \pm 87.79$ & $1274.17 \pm 91.38$ & ns \\
\hline Empty Intestine & $1127.69 \pm 74.26$ & $1199.17 \pm 77.29$ & ns \\
\hline Omental adipose tissue & $1155.38 \pm 203.12$ & $992.50 \pm 211.41$ & ns \\
\hline Cardiac adipose tissue & $54.62 \pm 8.76$ & $52.50 \pm 9.71$ & ns \\
\hline Renal adipose tissue & $372.38 \pm 89.92$ & $172.00 \pm 93.59$ & ns \\
\hline \multicolumn{4}{|l|}{ Carcass components (kg) } \\
\hline Hot carcass & $16.51 \pm 1.27$ & $15.69 \pm 1.33$ & ns \\
\hline Cold carcass & $15.77 \pm 1.22$ & $14.72 \pm 1.27$ & ns \\
\hline Left half-carcass & $7.88 \pm 0.61$ & $7.36 \pm 0.63$ & ns \\
\hline Leg & $2.40 \pm 0.25$ & $2.23 \pm 0.23$ & ns \\
\hline Shoulder & $1.65 \pm 0.10$ & $1.56 \pm 0.11$ & ns \\
\hline Loin & $0.51 \pm 0.15$ & $0.53 \pm 0.16$ & ns \\
\hline Neck & $0.73 \pm 0.04$ & $0.69 \pm 0.05$ & ns \\
\hline Rib & $2.45 \pm 0.26$ & $2.34 \pm 0.27$ & ns \\
\hline
\end{tabular}

ns: not significant $(\mathrm{p}>0.05) ; *(\mathrm{p}<0.05) ; * *(\mathrm{p}<0.01)$.

Sig.: Significance

Source: Elaboration of the authors.

On the anatomical dissection of the loin (Table $5)$, there was a higher incidence $(\mathrm{p}<0.05)$ of bone tissue in the DCM group compared to the WDCM group, while the latter exhibited higher mean values of muscle fat (longissimus dorsi) $(\mathrm{p}<0.05)$ than the group fed with detoxified castor meal (Table 5).
Food group had no effect $(\mathrm{p}>0.05)$ on the fatty acid profile (Table 6). In the muscle tissue used for gene expression analysis (Table 7), the expression of IGF-I was similar between groups ( $p>0.05)$, but IGF-II and SelW were upregulated in the DCM group. 
Table 5. Means and standard errors of dissection and proximate composition of the longissimus dorsi muscle after 480 days of feeding.

\begin{tabular}{|c|c|c|c|}
\hline Parameters & WDCM & $\mathrm{DCM}$ & Sig. \\
\hline \multicolumn{4}{|l|}{ Dissection (g) } \\
\hline Loin weight & $510.63 \pm 42.32$ & $536.33 \pm 37.24$ & ns \\
\hline Muscle & $252.89 \pm 21.20$ & $246.56 \pm 23.25$ & ns \\
\hline Bone & $104.50 \pm 11.07$ & $139.46 \pm 12.50$ & $*$ \\
\hline Connective & $76.64 \pm 7.73$ & $77.93 \pm 7.05$ & ns \\
\hline Adipose & $60.94 \pm 9.05$ & $45.44 \pm 7.63$ & ns \\
\hline \multicolumn{4}{|l|}{ Composition (\%) } \\
\hline Moisture & $75.95 \pm 0.37$ & $76.34 \pm 0.22$ & ns \\
\hline Ash & $1.16 \pm 0.09$ & $1.34 \pm 0.06$ & ns \\
\hline Total lipids & $2.77 \pm 0.25$ & $1.99 \pm 0.17$ & $* *$ \\
\hline Protein & $20.11 \pm 0.36$ & $20.32 \pm 0.17$ & ns \\
\hline
\end{tabular}

ns: not significant $(\mathrm{p}>0.05) ; *(\mathrm{p}<0.05) ; * *(\mathrm{p}<0.01)$.

Sig.: Significance

Source: Elaboration of the authors.

Table 6. Means and standard errors of fatty acid concentrations in the loin lipid extract after 480 days of feeding.

\begin{tabular}{rcccc}
\hline Fatty acid & & WDCM & DCM & Sig. \\
\hline Decanoic & C10:1 & $0.13 \pm 0.02$ & $0.16 \pm 0.01$ & $\mathrm{~ns}$ \\
Tridecanoic & $\mathrm{C} 13: 0$ & $0.20 \pm 0.03$ & $0.18 \pm 0.03$ & $\mathrm{~ns}$ \\
Myristic & $\mathrm{C} 14: 0$ & $1.63 \pm 0.13$ & $1.60 \pm 0.11$ & $\mathrm{~ns}$ \\
Myristoleic & $\mathrm{C} 14: 1$ & $0.08 \pm 0.01$ & $0.09 \pm 0.01$ & $\mathrm{~ns}$ \\
Pentadecanoic & $\mathrm{C} 15: 0$ & $0.73 \pm 0.14$ & $0.88 \pm 0.23$ & $\mathrm{~ns}$ \\
Palmitic & $\mathrm{C} 16: 0$ & $22.86 \pm 0.65$ & $22.31 \pm 0.66$ & $\mathrm{~ns}$ \\
Sapienic & $\mathrm{C} 16: 1 \mathrm{n}-10$ & $0.92 \pm 0.05$ & $1.09 \pm 0.08$ & $\mathrm{~ns}$ \\
Palmitoleic & $\mathrm{C} 16: 1 \mathrm{n}-7$ & $1.43 \pm 0.11$ & $1.43 \pm 0.08$ & $\mathrm{~ns}$ \\
Margaric & $\mathrm{C} 17: 0$ & $1.51 \pm 0.14$ & $1.42 \pm 0.11$ & $\mathrm{~ns}$ \\
Heptadecenoic & $\mathrm{C} 17: 1$ & $0.77 \pm 0.04$ & $0.89 \pm 0.11$ & $\mathrm{~ns}$ \\
Stearic & $\mathrm{C} 18: 0$ & $15.89 \pm 0.63$ & $16.52 \pm 0.90$ & $\mathrm{~ns}$ \\
Oleic & $\mathrm{C} 18: 1 \mathrm{n}-9$ & $39.38 \pm 1.64$ & $38.58 \pm 0.95$ & $\mathrm{~ns}$ \\
Elaidic & $\mathrm{C} 18: 1 \mathrm{n}-9$ & $0.18 \pm 0.04$ & $0.17 \pm 0.04$ & $\mathrm{~ns}$ \\
Linoleic & $\mathrm{C} 18: 2 \mathrm{n}-6$ & $3.68 \pm 0.44$ & $3.75 \pm 0.47$ & $\mathrm{~ns}$ \\
Linolelaidic & $\mathrm{C} 18: 2 \mathrm{n}-6$ & $0.18 \pm 0.03$ & $0.16 \pm 0.09$ & $\mathrm{~ns}$ \\
Linolenic & $\mathrm{C} 18: 3$ & $0.23 \pm 0.03$ & $0.22 \pm 0.02$ & $\mathrm{~ns}$ \\
Eicosenoic & $\mathrm{C} 20: 1$ & $0.14 \pm 0.01$ & $0.13 \pm 0.01$ & $\mathrm{~ns}$ \\
Arachidonic & $\mathrm{C} 20: 4$ & $0.48 \pm 0.13$ & $0.62 \pm 0.11$ & $\mathrm{~ns}$ \\
Behenic & $\mathrm{C} 22: 0$ & $0.28 \pm 0.06$ & $0.29 \pm 0.06$ & $\mathrm{~ns}$ \\
Erucic & $\mathrm{C} 22: 1$ & $0.12 \pm 0.01$ & $0.12 \pm 0.01$ & $\mathrm{~ns}$ \\
SFA & - & $43.10 \pm 0.74$ & $43.21 \pm 1.33$ & $\mathrm{~ns}$ \\
UFA & - & $47.73 \pm 1.41$ & $47.42 \pm 1.24$ & $\mathrm{~ns}$ \\
MUFA & - & $43.16 \pm 1.73$ & $42.66 \pm 1.00$ & $\mathrm{~ns}$ \\
PUFA & - & $4.57 \pm 0.49$ & $4.76 \pm 0.50$ & $\mathrm{~ns}$ \\
UFA/SFA & - & $1.11 \pm 0.04$ & $1.10 \pm 0.04$ & $\mathrm{~ns}$ \\
\hline
\end{tabular}

ns: not significant $(\mathrm{p}>0.05) ; *(\mathrm{p}<0.05) ; * *(\mathrm{p}<0.01)$.

SFA: saturated fatty acids; UFA: unsaturated fatty acids; MUFA: monounsaturated fatty acids; PUFA: polyunsaturated fatty acids; Sig.: Significance.

Source: Elaboration of the authors. 
Table 7. Means and standard errors of gene expression (arbitrary units) in loin muscle tissue after 480 days of feeding. Data converted to $\log _{10}$.

\begin{tabular}{lcccc}
\hline Parameter & & WDCM & DCM & Sig. \\
\hline Loin muscle & & & & $* *$ \\
& SelW & $2.11 \pm 0.06$ & $2.97 \pm 0.13$ & ns \\
& IGF-I & $2.11 \pm 0.06$ & $2.04 \pm 0.06$ & $* *$ \\
\hline
\end{tabular}

ns: not significant $(\mathrm{p}>0.05) ; *(\mathrm{p}<0.05) ; * *(\mathrm{p}<0.01)$.

Sig.: Significance.

Source: Elaboration of the authors.

\section{Discussion}

Castor meal is a promising byproduct for ruminant feeding, as a substitute for the traditional sources of protein, but its use has not been possible due to the presence of toxic (ricin and ricinine) and allergenic elements (CB-1A) in its composition, as well as a lack of technology that is conducive to achieving a safe feed at competitive prices (SEVERINO; LIMA; BELTRÃO, 2005). Thus, this byproduct can only be used in animal feeding after an extensive chemical or physical detoxification process to deactivate the toxic proteins (RIBEIRO; ÁVILA, 2006). Chemical detoxification with $\mathrm{CaO}$ effectively denatured the ricin, as the corresponding band of this toxic protein was not detected in the polyacrylamide gel after electrophoresis. This procedure is considered operationally simple and potentially economically viable for the producers.

The alkaline treatment is based on increasing the $\mathrm{pH}$ (12.5) relative to the isoelectric point of ricin (5.2 to 5.5) (KABAT; HEIDELBERG; BEZER, 1947), turning the net charge of the protein negative, causing an electrostatic repulsion and the breaking of the hydrogen bonds responsible for maintaining the tridimensional structure, resulting in the loss of function of this protein. Oliveira (2008) reported an increased efficiency when denaturating ricin by alkaline treatment using calcium hydroxide or $\mathrm{CaO}$ diluted in water $(1: 10)$ at a dose of $60 \mathrm{~g} / \mathrm{kg}$ of meal. Anandan et al. (2005) observed a complete elimination of ricin subunits when treating castor meal with $\mathrm{Ca}(\mathrm{OH})_{2}$ at a dose of $40 \mathrm{~g} / \mathrm{kg}$ of meal.
The biochemical composition of the blood plasma of ruminants faithfully reflects the metabolic condition of the tissue, enabling the evaluation of tissue damage, organ dysfunction, animal adaptation to nutritional and physiological challenges and metabolic imbalances that are specific or result from nutritional imbalances (COTE; HOFF, 1991). Consequently, the dietary treatment did not influence the protein status (urea and albumin) in the metabolic profile of the goats. According to Eckersall (2008), the urea concentrations in the blood is a good short-term indicator of protein nutritional status in ruminants, as it reflects the ammonia concentration in the rumen, which in turn is determined by the protein catabolism by the ruminal microbiota and the animal's tissue. Albumin synthesis is influenced by long-term protein nutritional status, which can be a good indicator of hepatic lesions (MORGAN; PETERS, 1971).

The urea and albumin levels found in the present study agree with the reference values established by Smith and Sherman (2009) for goats. Silva et al. (2010) also offered detoxified castor meal to finishing sheep, but for a short period of time, and observed blood urea within the normal physiological limits for the species. Ziguer et al. (2012) also observed normal albumin levels in sheep fed soybean hulls for 47 days.

The hepatic function tests are the main indicators of hepatocellular alterations and mainly involve enzyme analysis, while creatinine is the main indicator of renal function because it is related to 
glomerular filtration rate. In the present study, renal and hepatic alterations were observed in the DCM group, whereas ALT, AST and HDL were within or close to the species' standards (SMITH; SHERMAN, 2009). Oliveira et al. (2010) did not find a dietary effect on the ALT or AST concentration in sheep fed for 21 days with castor meal, treated or untreated, and no clinical symptoms of ricin toxicity were observed. Albin, Davis e Zinn (1969) also did not see any clinical symptom of toxicity in cattle fed with diets containing untreated castor meal for over 90 days. Andreazzi and Consolaro (1997) offered diets with cottonseed to goats for 6 months and did not see any alterations in hepatic or renal function, and no sign of toxicity caused by gossypol.

Quantitative and qualitative evaluation of the components of the carcass of small ruminants can be influenced by many factors, such as age, gender, breed and, especially, the type of diet (ALMEIDA JUNIOR et al., 2004). In the present study, the anatomical and carcass components were not affected by including detoxified castor meal in the diet.

In a study performed by Silva et al. (2010) on goats subjected to diets including up to $4 \%$ licuri oil, no influence of the diet was observed on the components or characteristics of the carcass. Hashimoto et al. (2007) also did not report any influence of replacing corn with soybean hull on the components of kid goat carcasses.

In the dissected loin tissue, significant differences were observed in the quantity of bone tissue between the experimental diets, but no influence of the diet was observed on the proportions of muscle and adipose tissues. Hashimoto et al. (2007) also noted an increase in bone tissue ratio, which resulted in a reduction of the proportion of adipose tissue in the loin, as the muscle contents did not vary among the goats fed with or without the soybean hull instead of corn.

Knowing the chemical composition of the meat is important to elucidate its nutritional value, as well as to design adequate diets for specific populations. The animals fed detoxified castor meal exhibited lower total lipid content, which is a positive change given that consumers prefer low-fat foods (LISBOA et al., 2010). The total lipids in the longissimus dorsi of the WDCM group were higher than the DCM group, but these values were both within the normal limits (1.5 to $13 \%$ total lipids) established by Zeola and Silva Sobrinho (2001) for goats. The other components of the proximate analysis performed in this study did not differ between diets. Moisture, protein and ash values were close to those found in the literature for this species (DHANDA; TAYLOR; MURRAY, 1999, DHANDA; et al., 2003; MADRUGA; ARRUDA; NASCIMENTO, 1999, MADRUGA et al., 2001; BESERRA et al., 2000, 2004), ranging from 70.80 to $80.25 \%, 18.50$ to $23.39 \%$ and 0.79 to $1.68 \%$, respectively. The fatty acid profile of meat is important to human health because people can reduce their risks of obesity, cancer and heart diseases by reducing lipid intake, especially cholesterol and saturated fatty acids, and increasing the consumption of monounsaturated and polyunsaturated fatty acids (JAKOBSEN, 1999; RHEE et al., 2000).

A growing interest in goat meat has been observed in recent years because of its dietary properties, because it has low cholesterol, saturated fat and calories when compared to other red meats (MADRUGA et al., 2001; WEBB; CASEY; SIMELA, 2005). The fatty acid profile of the longissimus dorsi muscle was not altered by including castor meal in the diet in this study. The main fatty acids identified in the meat were oleic (C18:1), palmitic (C16:0) and stearic (C18:0). Similar results have been observed in goat meat by other authors (BANSKALIEVA; SAHLU; GOETSCH, 2000; DHANDA; TAYLOR; MURRAY, 2003; MADRUGA et al., 2005). A higher unsaturated fatty acid percentage was found, and consequently, the unsaturated/saturated fatty acid ratio was higher than 1.0, which characterizes this meat as appropriate, from a dietary point of view, to be consumed by people with hypercholesterolemia. 
The same findings were observed by Madruga et al. (2001, 2008) when evaluating the fatty acid profile of goats. They observed values of 0.10 to 0.13 for the PUFA/SFA ratio in goat meat, which supports our findings.

Nutrigenomics is a new science of the postgenomic age that aims to clarify the complex interactions between the chemical components of diets (nutrients) and the genetic material of the individuals (genotype) by using technologies developed to analyze the transcriptome (MUTCH; WAHLI; WILLIAMSON, 2005).

SelW gene expression was higher in the DCM than the WDCM animals. SelW is a small selenoprotein (85-88 amino acids), and the highest concentrations of this protein are found in the heart and skeletal muscle of animals (VENDELAND et al., 1995). SelW can be considered a good putative sign that an adequate diet is being provided (CASSAR-MALEK et al., 2009). In studies with calves fed in a grazing system vs. confinement, a high alteration in the expression of the SelW gene was observed, and the expression levels of this gene could be a putative sign of a grazing system and serve as a tool for tracing bovine meat production (CASSAR-MALEK et al., 2009).

IGF-I and IGF-II are involved in the proliferation and differentiation of skeletal muscle tissue (FLORINI; EWTON; COOLOCAN, 1996; PENG et al., 1997). We observed that including detoxified castor meal in the diet influenced the expression of the IGF-II gene, whereas no effect was observed on the expression of the IGF-I gene. Kalbe, Mau and Rehfeldt (2008) analyzed different levels of isoflavones on the diet of pigs and, as in the present study, found no change in IGF-I gene expression in skeletal muscle.

\section{Conclusion}

The detoxified castor meal did not cause any macroscopic alterations to the anatomical or carcass components of goats, even after being administered for a long period. However, the differences in SEW and IGF-II gene expression between groups suggests that further investigations must be performed to determine the long-term effects of using this residue in animal feeding.

\section{Acknowledgments}

Financing institution: National Council for Scientific and Technological Development (Conselho Nacional de Desenvolvimento Científico e Tecnológico - CNPq) (Proc. N.578189/2008-9). The authors thank the technical team of the Dr. Esaú Accioly de Vasconcelos Agricultural Research Farm for their support and help in handling the animals. The authors thank Dr. Hilton Cesar Rodrigues Magalhães, EMBRAPA Frutos Tropicais, Fortaleza, Ceará, for the fatty acid profile analysis.

\section{References}

ABDAlla, A. L.; SILVA FILHO, J. C.; GODOIS, A. R.; CARMOS, C. A.; EDUARDO, J. L. P. Utilização de subprodutos da indústria de biodiesel na alimentação de ruminantes. Revista Brasileira de Zootecnia, Viçosa, MG, v. 37, p. 260-268, 2008. Suplemento Especial.

ABREU, F. R.; VIEIRA, J. N. S.; RAMOS, S. Y. Programa nacional para a produção e uso do biodiesel: diretrizes, desafios e perspectivas. Revista de Política Agrícola, Brasília, ano 15, n. 3, p. 5-18, 2006.

ALBIN, R. C.; DAVIS, W. H.; ZINN, D. W. Castor meal for growing-finishing steers. Journal of Animal Science, Illinois, v. 28, p. 125-152, 1969. Supplement 1

ALMEIDA JUNIOR, G. A.; COSTA, C.; MONTEIRO, A. L. G.; GARCIA, C. A.; MUNARI, D. P.; NERES, M. A. Desempenho, características de carcaça e resultado econômico de cordeiros criados em creep feeding com silagem de grãos úmidos de milho. Revista Brasileira de Zootecnia, Viçosa, MG, v. 33, n. 4, p. 1048-1059, 2004.

ANANDAN, S.; ANIL KUMAR, G. K.; GHOSH, J.; RAMACHANDRA, K. S. Effect of different physical and chemical treatments on detoxification of ricin in castor cake. Animal Feed Science and Technology, Amsterdam, v. 120, n. 1, p. 159-168, 2005.

ANDREAZZI, M. A.; CONSOLARO, M. E. L. Avaliação 
da toxicidade do gossipol em caprinos machos. Revista de Ciências humanas da UNIPAR, Umuarama, v. 5, n. 17, p. 11-18, 1997.

ASSOCIATION OF OFFICIAL ANALYTICAL CHEMISTS - AOAC. Official methods of analysis. 16. ed. Arlington: AOAC, v. 2, 1990. 1298 p.

AZEVEDO, D. M. P.; LIMA, E. F. (Ed.). O Agronegócio da mamona no Brasil. Brasília: Embrapa Informação Tecnológica, 2001. 350 p.

BANSKALIEVA, V.; SAHLU, T.; GOETSCH, A. L. Fatt y acid composition of goat muscle and fat depots: a review. Small Ruminant Research, Amsterdam, v. 37, n. 64, p. 255-268, 2000.

BARBIERI, L.; BATTELLI, M. G.; STIRPE, F. Ribosome-inactivating proteins from plants. Biochimica et Biophysica Acta. Amsterdam, v. 1154, n. 3-4, p. $237-$ 282, 1993.

BARROS, L. V.; PAULINO, M. F.; DETMANN, E.; VALADARES FILHO, S. C.; LOPES, S. A.; ROCHA, A. A.; VALENTE, E. E. L.; ALMEIDA, D. M. Replacement of soybean meal by treated castor meal in supplements for grazing heifer during the dry-rainy season period. Revista Brasileira de Zootecnia, Viçosa, MG, v. 40, n. 4, p. 843-851, 2011.

BELTRÃO, N. E. M.; CARTAXO, W. V.; PEREIRA, S. R. P.; SOARES, J. J.; SILVA, O. R. R. F. O cultivo sustentável da mamona no Semi-árido Brasileiro. Campina Grande, PB: EMBRAPA-CNPA, 2005. 23 p.

BESERRA, F. J.; MADRUGA, M. S.; LEITE, A. M.; DA SILVA, E. M. C.; MAIA, E. L. Effect of age at slaughter on chemical composition of meat from Moxotó goats and their crosses. Small Ruminant Research, Amsterdam, v. 55, n. 1-3, p. 177-181, 2004.

BESERRA, F. J.; MONTE, A. L. S.; BEZERRA, L. C. N. M.; NASSU, T. R. Caracterização química da carne de cabritos da raça Moxotó e de cruzas Pardo Alpina $\mathrm{x}$ Moxotó. Pesquisa Agropecuária Brasileira, Brasília, DF, v. 35, n. 1, p. 171-177, 2000.

BRASIL. Ministério da Agricultura, Pecuária e Abastecimento. Regulamento da inspeção industrial e sanitária de produtos de origem animal - RIISPOA. Brasília, 1980. $166 \mathrm{p}$.

CASSAR-MALEK, I.; JURIE，C.; BERNARD, C.; BARNOLA, I.; MICOL, D.; HOCQUETTE, J. F. Pasture-feeding of charolais steers influences skeletal muscle metabolism and gene expression. Journal of physiology and pharmacology, Krakow, v. 60, p. 83-90, 2009. Supplement 3.

CESAR, M. F.; SOUSA, W. H. Carcaças ovinas e caprinas - obtenção, avaliação e classificação. Uberaba, MG: Ed. Agropecuária Tropical. 2007. 147 p.

COTE, J. F.; HOFF, B. Interpretation of blood profiles in problem dairy herds. The Bovine Practitioner, Stillwater, v. 26, p. 7-11, 1991.

DHANDA, J. S.; TAYLOR, D. G.; MURRAY, P. J. Part2. carcass composition and fatty acid profiles of adipose tissue of male goats: effects of genotype and liveweigth at slaughter. Small Ruminant Research, Amsterdam, v. 50, n. 1, p. 67-74, 2003.

DHANDA, J. S.; TAYLOR, D. G.; MURRAY, P. J.; MCCOSKER, J. E. The influence of goat genotype on the production of capretto and chevon carcasses. 4. Chemical composition of muscle and fatty acid profiles of adipose tissue. Meat Science, Amsterdam, v. 52, n. 4, p. $375-379,1999$.

ECKERSALL, P. D. Proteins, Proteomics and the Dysproteinemias. In: KANEKO, J. J.; HARVEY, J. W.; BRUSS, M. L. Clinical biochemestry of domestical animal. 6. ed. London: Academic Press, 2008. cap. 5, p. 117-155.

EUROPEAN FOOD SAFETY AUTHORITY - EFSA. Scientific opinion of the panel on contaminants in the food chain on a request from the european commission on ricin as undesirable substances in animal feed. The EFSA Journal, Parma, v. 726, n. 9, p. 1-38, 2008.

FLORINI, J. R.; EWTON, D. Z.; COOLOCAN, S. A. Growth hormone and the insulin-like growth factor system in myogenesis, Endocrine Reviews, Baltimore, v. 17, n. 5, p. 481-517, 1996.

HASHIMOTO, J. H.; ALCALDE, C. R.; SILVA, K. T.; MACEDO, F. A. F.; MEXIA, A. A.; SANTELLO, G. A.; MARTINS, E. N.; MATSUSHITA, M. Características de carcaça e da carne de caprinos Boer x Saanen confinados recebendo rações com casca do grão de soja em substituição ao milho. Revista Brasileira Zootecnia, Viçosa, MG, v. 36, n. 1, p. 165-173, 2007.

JAKOBSEN, K. Dietary modifications of anim al fats: Status and future perspectives. Fett Lipid, Weinheim, v. 101, n. 12, p. 475-483, 1999.

KABAT, E. A.; HEIDELBERGER, M.; BEZER, A. E. A study of the purification and properties of ricin. Journal of Biological Chemistry, Baltimore, v. 168, n. 2, p. 629639, 1947.

KALBE, C.; MAU, M.; REHFELDT, C. Developmental changes and the impact of isoflavones on mRNA expression of IGF-I receptor, EGF receptor and related growth factors in porcine skeletal muscle cell cultures. Growth Hormone \& IGF Research, London, v. 18, n. 5, p. 424-433, 2008. 
LiSBOA, A. C. C.; FURTADO, D. A.; MEDEIROS, A. N.; COSTA, R. G.; QUEIROGA, R. C. R. E.; BARRETO, L. M. G.; PAULO, J. L. A. Avaliação da qualidade da carne de cabritos nativos terminados com dietas contendo feno de Maniçoba. Revista Brasileira de Saúde Produção Animal, Salvador, BA, v. 11, n. 4, p. 1046-1055, 2010.

MADEIRA JUNIOR, J. V.; MACEDO, J. A.; MACEDO, G. A. Detoxification of castor bean residues and the simultaneous production of tannase and phytase by solid-state fermentation using Paecilomyces variotii. Bioresource Technology, New York, v. 102, n. 15, p. 7343-7348, 2011.

MADRUGA, M. S.;ARRUDA, S. G. B.; NASCIMENTO, J. A. Castration and slaughter age effects on nutritive value of the "Mestiço" goat meat. Meat Science, Amsterdam, v. 52, n. 2, p. 119-125, 1999.

MADRUGA, M. S.; GALVÃO, M. S.; COSTA, R. G.; BELTRÃO, S. E. S.; SANTOS, N. M.; CARVALHO, F. M.; VIARO, V. D. Perfil aromático e qualidade química da carne de caprinos Saanen alimentados com diferentes níveis de concentrado. Revista Brasileira de Zootecnia, Viçosa, MG, v. 37, n. 5, p. 936-943, 2008.

MADRUGA, M. S.; NARAIN, N.; SOUZA, J. G.; COSTA, R. G. Castration and slaugter age effects on fat components of the "mestiço" goat meat. Small Ruminant Research, Amsterdam, v. 42, n. 1, p. 75-80, 2001.

MADRUGA, M. S.; SOUSA, W. H.; ROSALES, M. D.; CUNHA, M. G. G.; RAMOS, J. L. F. Qualidade da carne de cordeiros santa Inês terminados com diferentes dietas. Revista Brasileira de Zootecnia, Viçosa, MG, v. 34, n. 1, p. 309-315, 2005.

MORGAN, E. H.; PETERS, T. The biosynthesis of rat serum albumin. V. Effect of protein depletion and refeeding on albumin and transferrin synthesis. Journal of Biological Chemistry, Baltimore, v. 246, n. 11, p. 3500-3507, 1971.

MUTCH, D. M.; WAHLI, W.; WILLIAMSON, G. Nutrigenomics and nutrigenetics: the emerging faces of nutrition. The Journal of the Federation of American Societies for Experimental Biology, New York, v. 19, n. 12, p. 1602-1616, 2005.

NATIONAL RESEARCH COUNCIL - NRC. Committee on the nutrient requirements of small ruminants. National Academy of Sciences, Washington, D.C: National Academy Press, 2007. 362 p.

OLIVEIRA, A. S. Co-produtos da extração de óleo de sementes de mamona e de girassol na alimentação de ruminantes. 2008. Tese (Doutorado em Zootecnia) Departamento de Zootecnia. Universidade Federal de Viçosa, Viçosa.
OLIVEIRA, A. S.; CAMPOS, J. M. S.; OLIVEIRA, M. R. C.; BRITO, A. F.; VALADARES FILHO, S. C.; DETMANN, E.; VALADARES, R. F. D.; SOUZA, S. M.; MACHADO, O. L. T. Nutrient digestibility, nitrogen metabolism and hepatic function of sheep fed diets containing solvent or expeller castorseed meal treated with calcium hydroxide. Animal Feed Science and Technology, Amsterdam, v. 158, n. 1, p. 15-28, 2010.

PENG, M.; PALIN, M. F.; VERONNEAU, S.; LEBEL, D.; PELLETIER, G. Ontogeny of epidermal growth factor (EGF), EGF receptor (EGFR) and basic fibroblast growth factor (bFGF) mRNA levels in pancreas, liver, kidney, and skeletal muscle of pig. Domestic Animal Endocrinology, Auburn, v. 14, n. 5, p. 286-294, 1997.

RHEE, K. S.; WALDRON, D. F.; ZIPRIN, Y. A.; RHEE, K. C. Fatty acid com-position of goat diets vs intramuscular fat. Meat Science, Amsterdam, v. 54, n. 4, p. 313-318, 2000.

RIBEIRO, N. M.; AVILA, F. D. F. Métodos para desintoxicação de tortas de oleaginosas. In: CONGRESSO DA REDE BRASILEIRA DE TECNOLOGIA DE BIODIESEL, Brasília, DF. Anais... Brasília, DF: MCT/ ABIPTI, v. 1, 2006. p. 34-37.

ROBB, J. G.; LABEN, R. C.; WALKER JUNIOR, H. G.; HERRING, V. Castor meal in dairy rations. Journal of Dairy Science, Champaign, v. 57, n. 4, p. 443-449, 1974.

RODRIGUES, R. A. Programa nacional de produção e uso de biodiesel: uma referência para a análise da formulação, implementação e avaliação de políticas públicas. Revista de Políticas Públicas e Gestão Governamental, Brasília, v. 6, n. 1, p. 9-25, 2007.

SEVERINO, L. S.; LIMA, R. L. S.; BELTRÃO, N. E. M. Composição química de onze materiais em substratos para produção de mudas. Campina Grande: Embrapa Algodão, 2005, v. 134, p. 31, 2005.

SILVA, D. C.; ALVES, A. A.; VASCONCELOS, V. R.; NASCIMENTO, H. T. S.; MOREIRA FILHO, M. A.; OLIVEIRA, M. E. Metabolismo dos compostos nitrogenados em ovinos alimentados com dietas contendo farelo de mamona destoxificado. Acta Scientiarum Animal Sciences, Maringá, v. 32, n. 2, p. 219-224, 2010.

SILVA, D. J.; QUEIROZ, A. C. Análise de alimentos: métodos químicos e biológicos. 3. ed. Viçosa, MG: Editora UFV, 2002. 235 p.

SILVA SOBRINHO, A. G. Aspectos quantitativos $e$ qualitativos da produção de carne ovina. Piracicaba: Embrapa Informação Tecnológica, 2001. 350 p.

SMITH, M. C.; SHERMAN, D. M. Goat medicine. 2. ed. Editora: Wiley-Blackwell, USA. 2009. 871 p. 
VAN SOEST, P. J.; ROBERTSON, J. B.; LEWIS, B. A. Methods for dietary fiber, neutral detergent fiber, and non starch polyssacarides in relation to animal nutrition. Journal of Dairy Science, Champaign, v. 74, n. 10, p. 3583-3597, 1991.

VENDELAND, S. C.; BEILSTEIN, M. A.; YEH, J. Y.; REAM, W. L.; WHANGER, P. D. Rat skeletal muscle selenoprotein W: cDNA clone and mRNA modulation by dietary selenium. Proceedings of the National Academy of Sciences of the U. S. A, Washington, v. 92, n. 19, p. 8749-8753, 1995.

VIEIRA, M. M. M.; CÂNDIDO, M. J. D.; BOMFIM, M. A. D.; SEVERINO, L. S.; ZAPATA, J. F. F.; BESERRA, L. T.; MENESES, A. J. G.; FERNANDES, J. P. B. Características da carcaça e dos componentes não-carcaça em ovinos alimentados com rações à base de farelo de mamona. Revista Brasileira de Saúde e Produção Animal, Salvador, v. 11, n. 1, p. 140-149, 2010.
WATSON, G. Note on ricin and abrin experiments. British Medical Journal, London, v. 11, n. 2, p. 1091, 1905.

WEBB, E. C.; CASEY, N. H.; SIMELA, L. Goat meat quality. Small Ruminant Research, Amsterdam, v. 60, n. 1-2, p. 153-166, 2005.

ZEOLA, N. M. B. L.; SILVA SOBRINHO, A. C. Composição química da carne ovina. Revista Nacional da Carne. São Paulo, v. 25, n. 292, p. 36-44, 2001.

ZIGUER, E. A.; BÜTTOW ROLL, V. F.; BERMUDES, R. F.; MONTAGNER, P.; PFEIFER, L. F. M.; DEL PINO, F. A. B.; CORREA, M. N.; DIONELLO, N. J. L. Desempenho e perfil metabólico de cordeiros confinados utilizando casca de soja associada a diferentes fontes de nitrogênio não-proteico. Revista Brasileira Zootecnia, Viçosa, MG, v. 41, n. 2, p. 449-456, 2012. 